\title{
Developing Culturally Responsive Teachers: Current Issues and a Proposal for Change in Teacher Education Programs
}

\author{
Huanshu Yuan ${ }^{1, *}$ \\ ${ }^{1}$ College of Education, University of Washington-Seattle, U.S.A. \\ *Correspondence: College of Education, University of Washington, U.S.A. E-mail: yuanshelly67@gmail.com
}

Received: October 10, 2017

Accepted: October 23, $2017 \quad$ Online Published: October 27, 2017

doi:10.5430/wje.v7n5p66

URL: https://doi.org/10.5430/wje.v7n5p66

\begin{abstract}
This paper examined current issues of educating culturally responsive teachers in teacher education programs from empirical researches. Focusing on constructing a culturally responsive knowledge base for teacher education students, this paper summarized obstacles for developing culturally responsive teachers, proposed multicultural approaches to establish a culturally responsive knowledge base for teacher education students, as well as presented practical implications to enhance the knowledge construction for preparing teachers for diversity. Aiming at stimulating reconsiderations of situating teacher education programs in multicultural context, this paper brought culturally responsive perspectives to empower pre-service and in-service teachers' teaching capacities to meet needs from their students with diverse cultural and racial backgrounds.
\end{abstract}

Keywords: culturally responsive teaching; teacher education; multicultural teacher education

\section{The Changing Demographic Features in Student and Teacher Population}

The population of the United States has always been characterized by racial, ethnic, cultural, and linguistic diversity (Villegas \& Davis, 2008). Schools in the United States are becoming more diverse today. During the recent decades, the percentage of students of color in American public schools increased from 22\% to 55\% (Dillon, 2006). If current trends continue, students of color will equal or exceed the percentage of their White peers. Language and cultural diversity is enriching the demographic variety in student population, at the same time, it also challenges teachers' instructional methods and effectiveness.

It is obviously that teachers will have increasing multicultural students in their classes who are shifting between degrees of comfort and discomfort with their own culture and identity and the school culture intertwined with cultural backgrounds and identities of teachers and their White American counterparts (Dilg, 2003). Seeing the increasing "non-Whiteness" in classrooms, especially in predominantly recognize White culture as "normal" and "majority" schools, teachers may become more aware of diversity and multicultural issues. Under this situation, teaching will not be simple regarded as the job that "looks deceptively simple" (Grossman, Hammerness \& McDonald, 2008, p.273).

One of the major challenges from the changing student demographics is described by Gay and Howard (2000) as the "demographic divide", wherein "teachers face the reality that they are most likely to come into contact with students from cultural, ethnic, linguistic, racial, and social class backgrounds different from their own" ( as sited in Howard, 2010, p.40). According to Howard's research, U.S. schools will continue to become learning spaces where an increasingly homogenous teaching population (mostly White, female, monolingual, and middle class) will interact with a mostly heterogeneous student population (increasingly students of color, who come from culturally and linguistically diverse and low-income backgrounds) (p.40). Recent data suggests that the proportion of the minority student population in the U.S. increased by more than 57\% between 1990 and 2000, and this growth is expected to expand by nearly another 50\% between 2000 and 2015 (Howard, 2010). Yet, current teacher preparation and practice for minority students may not proportionately match the growth in students' diversities, suggesting that the "demographic divide" between minority and the homogeneous teaching force will continue to expand.

The impact of this demographic divide on the changing demographics of teaching force has also been addressed by Villegas and Davis (2008) in their study of preparing teachers to confront racial and ethnic disparities in schools. 
Their study proposed the issue of the minority teacher shortage, due to "historically, students of color have had significantly lower high school completion rates than White students; such loss of minority students substantially reduces the pool of eligible candidates of color for teacher education programs in higher education" (p.591). The reduce of minority participation in the teaching force in American higher education and the declining enrollments among Asian, Black, and Hispanic students in teacher education programs results in the teaching force is overwhelming White European American (Cochran-Smith, 2004).

The proportional representation of minorities in teaching may drop even further less active measures are taken to reverse this pattern (Smith, as cited in Villegas \& Lucas, 2002). The most recent information available on the country's teaching force and community presents a profile that is quite different from the student profile, with White faculties currently accounting for some $76.83 \%$ of the teaching force and faculties of color collectively accounting for $23.17 \%$ (National Center for Education Statistics, 2011). Information about who is currently preparing to teach indicates a pattern that is generally similar to that of the current teaching force (Villegas \& Lucas, 2002), with White students representing the vast majority (80\%-93\%) of students enrolled in collegiate education programs.

The decline of minority participation in the teaching force and teacher education programs at colleges and universities will decrease faculties' cultural sensitivity and awareness. It will also lead to marginalizing linguistic and cultural minority students in the White-European-English dominate academic environment. As Villegas and Lucas (2002) reported in their study, the relative absence of teachers of color is "also problematic in that it deprives students of color of vital role models, cultural brokers, and advocates in elementary and secondary schools" (p.xii). Faculties tend not to have the same cultural frames of reference and points of view as their students because, as Gay (1993) pointed out, "they live in different existential worlds" (p.287).

Consequently, these faculties often have difficulty functioning as effective role models for students (Villegas \& Lucas, 2002), or serving as cultural brokers and cultural agents (Gay, 1993; Goodwin, 2000) who can assist students bridge to home-school differences and cultural gaps. They also often have difficulty constructing curriculum, instruction, and interactional patterns that are culturally responsive. Thus indicates that the students in the greatest academic need are least likely to have access to educational opportunities congruent with their life experiences and cultural heritages (Cochran-Smith, 2004). The rapid increase in the culturally and linguistically diverse student population is changing the fabric of the American classroom, at the same time, the academic achievement gap between these students and others in the schools is also widening (Committee on Multicultural Education, 2008).

\section{Marginal Status in the Teacher Education Literature and Training}

Traditional conceptions of teaching are narrowly defined and addressed in teacher education program in colleges and universities. The over-concern about teachers' expertise on subject content they teach ignores the diversity and complexity embedded in the context of teaching in multicultural school settings. The historically dominant notions of academically oriented teacher education and preparation in colleges and universities have focused on the Western, White, middle class biases in the curriculum that have led to an absence of non-Western and culturally diverse perspectives in the education of U.S. teachers and college faculties (Zeichner, 1990). Teacher education researchers have found that many teacher educators are unprepared to teach culturally diverse students registered in their teacher education programs (Irvine, 1995; Gay, 2000); thus will lead to a chain reaction in those prospective teachers' inadequate teaching practices toward their students from minority groups.

Understanding diversity as it affects teaching and learning is important for teacher students who are preparing to teach in the future multicultural classrooms, as well as for teacher educators. Appreciating diversity and applying that understanding to teacher educators and prospective teachers is vital to meeting the many learning styles, communication patters, and cultural subtexts presents in the multicultural student population teachers serve. However, Landson-Billings (2009) demonstrated that many in-service teachers who have been teaching a very long time are still struggle to teach in affirming and effective ways with multicultural students, due to a lack in the literature on the experiences of ethnic minority groups, such as African American students specifically, in their teacher education programs.

The lack of cultural relevant literature is not only limited to African American culture. Ellerbrock and Cruz (2014) pointed out that a lack of familiarity with the breadth and depth of diversity issues, combined with difficulty providing a real-world context within a relatively homogenous university system, and resistance to infusing diversity in teacher education programs throughout teacher education curricula make it difficult to get teacher education programs to accept the need to embrace diversity as a goal and infuse diversity into the curricula and courses to teacher education students. Resistances not only come from lacking of literature support, but also emerge from 
teacher education faculties who may actively resist incorporate diversity into their courses, believing "such topics have no place in their fields' curricula" (Ellerbrock \& Cruz, 2014, p.15). Teachers in both the dominant White groups and the cultural and racial minority groups report that they often feel inadequately prepared and trained in their own formal training to teach a diverse student population (Marchesani \& Adams, as cited in Ellerbrock and Cruz, 2014). Even with systematic and professional training in teacher education programs, many teacher educators and instructors indicate themselves "ill-equipped to facilitate such difficult and potentially controversial conversations in their courses with their students" (Ellerbrock \& Cruz, 2014, p.16).

Tomorrow's teachers and university faculties will need to be well prepared to effectively and appropriately deal with issues of race, culture, ethnicity, and language. The teacher preparation programs need to be more responsive to the needs of this growing segment of the student population (Villegas \& Lucas, 2002). The problem of lacking of multicultural perspectives and materials in teacher education programs will continue to challenge current teacher education programs, and teaching practice of educating White, monolingual, and mostly female teacher education students in college and university settings to teach their future diverse students effectively.

\section{3. "Common Education" and the Changing Conceptions of Learning}

Villegas (2008) indicated that due to the highly diverse population of the United States, the public schools of this country are expected to function as a major role in bringing about the unification of the nation by providing a "common education" to students from diverse groups, which offers everyone "the knowledge and skills they need for successful integration into American society, regardless of differences in backgrounds" (p.551). Consequently, the "great equalizer" of public education sets a prime objective of schools is to "eradicate cultural and linguistic differences and instill in all children a common set of values---namely, those of the White, Protestant, middle-class, English-speaking dominant group in American society" (Villegas, 2008, p.552). This assimilationist thinking has not only informed public school practices aimed at Americanizing immigrants, but also embedded in the belief of training teachers to effectively deliver the concept of Americanization and the knowledge and skills valued by common education to students with diverse cultural and racial backgrounds.

Accordingly, under the influence of a transmission framework which defined the role of students is largely "passive receiving" the knowledge comprising the curriculum and taught by their teachers, teachers are thought to need only knowledge of their subject matter and a uniform method of instruction (Villegas, 2008). This notion leads to issues reported in Sleeter's (2008) review of the literature: White pre-service teachers usually bring very little cultural diversity awareness and understanding to teaching. Moreover, they have little knowledge of racism, discrimination, and structural aspects of inequality, along with their stereotypical beliefs about urban and minority students.

As Villegas (2008) claimed, "the changing demographics of elementary and secondary schools coupled with persistent racial and ethnic achievement gaps demand fundamental changes in the ways teachers are prepared" (p.557). There is an urgent need to improve substantially White domain teacher education for effectively teaching diverse students with affirming and caring attitudes. As Sleeter (2008) addressed, White teachers can learn to teach diverse student populations well by situating in culturally responsive teacher education programs. Not only teachers from the dominate group, teachers from every cultural and racial background need learn to embrace the increasing multiple diversities among students, schools, and teachers themselves, as well as incorporate their cultural awareness into teaching practice. Before they could accomplish this goal, they need to be educated and trained in culturally responsive teacher education programs.

\section{A Disparity in Teacher Education and Practice In Diverse Classroom Settings}

Schorr (2013) pointed out the misconnection between teacher training and practicing exist. Schorr's study notes that typically, teacher preparation programs and education schools put much of their attention and energy into theory instead of preparing teachers for the daily realities of classroom. This issue is also mentioned by Knowles's (2013), who demonstrated that teacher education programs usually have a strong grounding in the subject area knowledge training, but lack of exposure to pedagogy of schooling and teaching in multicultural school settings. This absence of culturally responsive practice in real classrooms overweighs the subject content knowledge, or "professional skill" training in teacher education programs.

Noted by McDonald et al (2008), there is still a disconnection between theoretical knowledge and teachers' practical work in the issue of diversity, social justice and multiculturalism. Currently, teacher education in the U.S. is built around "a collection of methods courses in which prospective teachers learn about what methods exist for teaching particular subjects and how they are grounded in educational theory and research" (Lampert, 2005, p.36), the 
emphasis may be more on educating teachers about instructional methods and less about learning to enact such practices effectively and accordingly to the cultural diverse context.

Lampert and Balls' (1998) researches noted that promote teaching for understanding and diversity is important to better prepare prospective teachers to effectively teaching in multiple diverse classrooms. Their studies indicate that discontinuities between teacher education and effective teaching practice exist; due to teacher educators "have little or no knowledge or real concern for teaching practice and training for diversity and complicities" (p.26). Thus leads to an over-concern with professional knowledge training than position teachers in an active and culturally sensitive role in relation to the knowledge they use and learn from diverse backgrounds students in practice (p.36).

Previous researches indicate that a theory-training-practice gap in teacher education exists, especially among teachers who have increasing numbers of ethnic minority and international students in class. According to the report from Committee on Multicultural Education (2008), most teachers in classrooms with increasing multicultural students have little or no training in the differential learning and development needs of these students. The data shows that of the total number of public school teachers across the nation, only " 12 percent of teachers who have culturally and linguistically diverse students in their classrooms have had eight or more hours of professional development specific to the needs of this student population" (NCES, as cited in Committee on Multicultural Education, 2008, p.666). Consequently, few teachers are prepared to provide instruction specifically designed to meet the "linguistic, cognitive, academic, and emotional development needs of these students" (Committee on Multicultural Education, 2008, p.666). As Irvine (2003) argued, professors and faculties in schools of education and teacher education programs have limited experiences with diverse population, and if those teacher education programs are not able to bridge the gap between teacher students' theory learning and teaching practice, how will preservice teachers acquire positive professional pedagogical skills and attitudes to teach culturally diver students?

\section{Empowering Culturally Responsive Teacher Education Programs}

\subsection{Rethinking How to Prepare Teachers for Diversity}

An important mission of teacher education is improving teacher candidates' professional content knowledge and teaching strategies, as well as promoting educational excellence and equity. One of the major aims of teacher education should be to assist teachers to develop the attitudes, knowledge, and skills needed to become thoughtful and approachable for every student in the multicultural academic environment. To achieve this goal, appropriate and comprehensive training to foster positive teaching attitudes towards diversity, build culturally responsive knowledge base, and situate teaching practice training in cultural context will become the central concern for accommodating teacher education programs to enhance teacher education students' capacities and abilities to teach in cultural and linguistic diverse classrooms.

Delpit (1995) pointed out that there is a silenced dialogue in teacher education for training teachers to teach students of color. Cultural, linguistic, and racial pluralism increases the difficulty of instructional methods for students, and challenges traditional pathways to educate teachers. The needs of multicultural students require foundation and pedagogical training courses about diversity in terms of international perspectives, identity, and cultural and racial differences in the curriculum of teacher education programs.

Cochran-Smith (2004) noted that U.S. teacher education programs only offer brief lessons on race and cultural differences. Teacher education programs focus mainly on instructions of foundation and methods courses that often frequently teach subject matter knowledge and instructional methods separate from racial, ethnic, and cultural concepts. A review by Howard and Aleman in 2008 revealed that most teacher education programs still had few substantive programs or courses that addressed issues of diversity. Other researchers on the topic of preparing teachers for diverse school settings have reached similar conclusions, arguing that "while there is a pressing need to prepare teachers for teaching diverse learners, issues pertaining to diversity have typically been separated from the rest of the teacher education curriculum" (Cochran-Smith et al, 2003; Landson-Billings, 1995; Zeichner \& Hoeft, 1996, as cited in Howard \& Aleman, 2008, p.157).The missing component of diversity in teacher education programs directly impacts prospective teachers' attitudes and practices, which leads to their deficit-based attitudes.

As Villegas and Lucas (2002) proposed in their research, preparing teachers who are culturally responsive is an urgent issue in teacher education. According to their research, there are two important issues need to be addressed by teacher education programs: "First of all, everyone entering the teaching profession regardless of background must be prepared to teach a racially, ethnically, economically, and linguistically diverse student population. Second, teacher education programs must also find ways to increase the number of minority teachers" (p.xii). However, 
despite the urgency of the demographic divide among student and teacher population, teacher education has been slow to respond to the shifting demographic landscape in their workplaces (Villegas \& Lucas, 2002). Most teacher education programs have taken limited steps to address the growing cultural, racial and ethnic imbalance between the teaching force and the student body; nor is there much evidence of serious work to address issues of diversity, culture, class, and language in the teacher education curriculum and contents (Villegas \& Lucas, 2002; Vavrus, 2002; Cochran-Smith, 2004).

The notion of embracing diversity and multicultural components into teacher education programs is promoted in the late 1970s and early 1980s, when many teacher education programs across the country began to include multicultural issues in the curriculum and add "the diversity course" or "the multicultural course" (Cochran-Smith, 2004, p.16). While seeking to addressing diversity issues into account, many teacher education programs have rhetorically embraced multicultural education, but seem unable to make necessary "multicultural across-the-curriculum changes despite the growing literature in the field during the 1990s" (Vavrus, 2002, p.19).

Simply adding courses of multicultural education to the teacher education programs cannot prepare prospective teachers adequately for a changing student population, nor can efforts of individual faculty members to redesign their own courses for diversity accomplish this goal (Villegas \& Lucas, 2002). In the absence of a broad vision for preparing culturally responsive teachers, such courses can be contradicted by the rest of the curriculum, marginalizing those individual efforts to address diversity issues (Villegas \& Lucas, 2002). Many multicultural education advocates argue for an infusion strategy whereby issues of diversity are addressed not only in specialized multicultural education courses but throughout the entire teacher education curriculum (Larkin, 1995; Villegas \& Lucas, 2002, p.xiii).

The limited components of multicultural education in teacher education programs' curriculum, learning materials, along with teacher education students' lack of pedagogical skills training and practical experiences in cultural diverse settings lead to a more fundamental problem: the growing cultural and racial mismatch between prospective teachers and their multicultural students. Researches show that many teachers from mainstream backgrounds with limited training of multicultural education view student diversity as an obstacle to overcome rather than as a valuable resource to build upon and that they hold low expectations for students of color (Villegas \& Lucas, 2002; Irvine, 2003). In response to the changing student population in schools, teacher education programs will need to reconsider the cultural responsiveness of established curriculum and courses, as well as develop a solid knowledge base of multicultural education and cultural diversity to better prepare teacher students to become qualified culturally responsive teachers.

\section{Constructing Teacher Education Students' Culturally Responsive Knowledge Base}

Teachers may not be culturally competent to create a learning environment that builds on students, especially minority students' cultural knowledge, social interaction patters, learning styles, and belief systems without receiving relevant knowledge base from teacher education programs (Pang, Kian \& Pak, 2004). As Rodriguez (1983) claimed, teachers must become understanding and knowledgeable enough to build on the students' diverse backgrounds instead of rejecting it. Colleges and universities offer teacher education programs play a central role in facilitate teacher students to "construct a solid knowledge base of cultural and racial diversity", as well as enable them to "understand their own and their students' culture, combine with the development of teaching skills consistent with the accepted purposes of education for a multicultural society" (Rodriguez, 1983, p.18).

However, as Vavrus (2002) indicated, most teacher education programs have generally perceived multicultural education as a possible elective or singular addition within a "Eurocentric core curriculum that is supported by conventional pedagogies and systems of evaluation" (p.1). Under this circumstance, the multicultural education key concepts and principles cannot be fully delivered to students in teacher education programs. Thus lead to the status of multicultural education in teacher education programs remain excluded from the central core of the knowledge base and curriculum setting. Most teacher education programs are still hesitant when it comes to incorporating multicultural education with depth and fidelity (Vavrus, 2002).

Teacher education is needed for cultivating pre-service teachers' positive teaching attitudes towards diversity and fostering skills in culturally pedagogy for them. The idea that classroom teachers and college faculties need to receive specific preparation and knowledge construction in order to work effectively with diverse student populations has been a part of professional discourse for a long time (Goodwin 1997). For example, Gay (1977) outlined three components for multicultural teacher education: knowledge, whereby "teachers become literate about ethnic group experiences" (p.34); attitudes to "help teachers examine their existing attitudes and feelings towards 
ethnic, racial, and cultural differences" (p.43); and skills to "translate their knowledge and sensitivities into school programs, curricular designs, and classroom instructional practices" ( $\mathrm{p} .48$ ). These competencies help prospective teacher candidates' improve their cultural knowledge and pedagogical abilities for teaching minority students in schools as well. Among these three components, acquiring multicultural knowledge base serves as the foundation of raising teachers' multicultural attitudes and developing their culturally responsive pedagogies.

\section{What Knowledge Teacher Education Students Need Besides Subject Matter Knowledge}

Feiman-Nemser (2008) highlighted the different kinds of knowledge that good and effective teaching depends on, including the knowledge teachers generate in practice. As she proposed, teachers need to know a great deal in order to enhance the academic learning of all students. They need solid knowledge of "subject matter and how to teach it to divers learners; they need to understand how diverse students grow and learn and how culture and race influence their learning; they need to know about curriculum, pedagogy, classroom organization and assessment, as well as understand the broad purposes of schooling and how those purposes affect their work" (Feiman-Nemser, 2008, p.699). Besides knowledge for teaching which can be learned from professional development and education courses, teachers need knowledge of teaching which can only be gained in the cultural context of their work.

Building a culturally responsive knowledge base is important for preparing teachers for diversity. Culture plays a critical role in learning and teaching. This reality needs to be included in the design of foundation courses. Foundation courses, which teach conceptual knowledge, and principles, could afford valuable multicultural guidelines for teachers to improve their practices (Foster et al., 2006). Since culture is central to student learning, teachers must become knowledgeable about their students' distinctive cultural backgrounds so they can effectively translate that knowledge into more appropriate instruction and curriculums (Goodwin, 1997; Gay, 2000).

\subsection{Personal Knowledge and Experience}

As Cochran-Smith (2004) indicated, in order to learn to teach in multicultural school settings, prospective teachers as well as experienced teachers and teacher educators need opportunities to examine much of "what is usually unexamined in the tightly braided relationships of language, culture, and power in schools and schooling" (p.49). This kind of examination inevitably begins with teachers' own cultural, racial, and educational backgrounds and teachers' own experiences as raced, classed, and gendered children, parents, and teachers in the world. The reconsideration of teachers' own personal knowledge and experience also inspires the knowledge question which is proposed by Cochran-Smith (2004) as the seeking of "what knowledge, interpretive frameworks, beliefs, and attitudes are necessary to teach diverse populations effectively, particularly knowledge and beliefs about culture and its role in schooling" (p.145). This question exposes the typical problem of the traditional knowledge base for teacher education concentrates on the "Western canon, omits most of what Luis Moll (1992) referred to as cultural funds of knowledge and thus limits what can be known" for students in teacher education programs" (p.145).

Melnick and Zeichner's (1997) research reported that a wide range of curriculum and instructional strategies are used to "attempt to socialize prospective teachers to see themselves as members of a culturally diverse society and to value cultures other than their own" (p.29). This approach of helping teacher education students situate themselves within the culturally diverse society and examine their attitudes towards others can bring positive impact on prospective teachers' attitudes and dispositions.

\subsection{Pedagogical Content Knowledge}

Howard and Aleman (2008) proposed the importance of enhancing teacher education students' pedagogical content knowledge in their research. They indicated that discussions of fundamental teaching capacity or essential knowledge for teachers should pay careful consideration to the importance of how content is delivered or made accessible to multicultural learners. As they mentioned in their study, teaching is a highly complex activity. Conceptions of teaching capacity for diverse students must include continued attention to pedagogical content knowledge, in particular, Howard and Aleman (2008) presented a notion of pedagogy must recognize complexity in students' learning, especially with regard to their background knowledge and individual culture.

Teacher capacity for diverse learners can be enhanced by the intersection of pedagogical content knowledge along with a complex notion of culture and learning. This intersection is necessary because it helps to provide insight about the type of knowledge that can be used in teaching divers learners. Some scholars have suggested that the importance of pedagogy is largely tied to an understanding of the cultural context is essential (Cole, 1996; Erickson, 2002; Gutierrez, 2002; as cited in Howard \& Aleman, 2008). As they have posited that effective teaching practice must recognize and respect the intricacies of cultural differences in order to be culturally recognizable and socially 
meaningful (Gay, 2000; Howard \& Aleman, 2008).

\subsection{Cultural Knowledge}

Larkin (1995) indicated that teaching requires knowledge of both the subject matter and the student. It follows that effective teaching requires not only knowledge of subject matter and students, but also of "the contextual fabric within which they meet" (p.7). Teaching in multicultural classrooms, developing knowledge of unfamiliar cultures students bring in to the classroom with them will be indispensable to a teacher's need to make sense of the subject matter, the students, or the contextual forces. Addressing this task is more complicated than simply offering ethnic study courses in which preservice teacher education students learn about the various ethnic minority groups in American society. Rather, Larkin (1995) provided that this broad area of cultural knowledge might be divided into three categories: "knowledge of the nature, functions, and processes of culture itself; knowledge of the cultural foundations of schools, teaching, learning, and subject matter; and content, language, and process knowledge relating to particular cultural groups" (p.7).

To achieve the goal of acquiring the cultural knowledge, Larkin proposed the notion of creating a "multicultural frame of mind" (p.8) to assist teacher education students in developing broader knowledge about the cultural foundation s of education and schooling. As Larkin (1995) indicated, most teacher education students have detailed knowledge about schools that is grounded directly in their particular and personal experiences, and this experiential knowledge base provides a very limited perspective from which to analyze and understand much that goes on in and around multicultural schools. Cultural knowledge should enable preservice students to comprehend social diversity, not only in terms of individual differences, but also "move them beyond their common habit of thinking about schools towards an understanding of schools as social institutions with embedded structures, norms, and recurrent practices which can and do systematically obstruct he educational development of some groups of students" (Liston and Zeichner, as cited in Larkin, 1995, p.8).

Most importantly, obtaining this knowledge base could help prospective teachers understand how culture and language influence the processes of cognition, learning, communication, and interaction styles which powerfully affect classroom climate and teaching-learning activities and effectiveness (Garcia, 1988; Shade 1989; Larkin, 1995). Moreover, multicultural education theorists have argued that teacher education programs need to employ a wide range of strategies to assist teacher education students in developing cross-cultural content knowledge, with suggesting that teacher education students should be allowed to "focus on in the study of one particular group in order to better understand the depth and richness of diverse cultural patterns" (Gay, as cited in Larkin, 1997, p.9).

The significances of enabling teacher education students to construct cultural knowledge also reflect in the process of reducing prejudice and creating cross-cultural awareness. Melnick and Zeichner (1997) presented how to provide teacher education students with cultural and historical knowledge to overcome their "cultural ignorance of groups different from their own" (p.29) and to avoid stereotypic responses to diverse cultural groups. As their research findings indicate, it is important to assist teacher education students learn how to learn about the students and the cultural communities in which their students come from and they will teach in.

\subsection{Culture Knowledge of Others}

Hollins (1997) illustrated the importance for prospective teachers to begin their professional preparation for teaching by constructing the knowledge base of themselves, the culture, and their students. What teachers and teacher education students need to understand is the relationship between students' home culture and school learning. Teachers need to understand how cultural perspectives influence students' approaches to learning, the curriculum content valued, and supportive social situations for learning (Hollins, 1997). The call for enriching teachers' knowledge base is also developed by Villegas and Lucas' (2002) study of fostering culturally responsive teaching in teacher education programs. They proposed following aspects that teachers need to know about their students to help them build bridges to learning: "Students' lives outside school; students' perceptions of school knowledge and belief in the potential of schooling to improve their lives in the future; students' relationships to subject matter; and community life" (p.81).

To accomplish this mission, teacher education students need to receive courses to teach them how to incorporate cultural knowledge into their daily classroom practices. Hollins presented several approaches to help prospective teachers and teacher education students acquire knowledge about their students from diverse cultural and experiential backgrounds including: "reflecting on their own beliefs about specific ethnic groups; interacting with those different from themselves through community field experiences; studying the cultural experiences and history of specific ethnic groups; identifying learning styles; and identifying culturally sensitive curriculum content and instructional 
strategies" (Zeichner, as cited in Hollins, 1997, p.102).

\subsection{Culturally Responsive Conceptions of Knowledge}

Murrel and Diez (1997) addressed the significance of constructing the multilayer knowledge base in teacher education programs to initiate teacher candidates' developments of their pedagogical skills and teaching attitudes by starting with a solid, comprehensive, and culturally responsive framework. Teachers need to begin the process of becoming culturally responsive and competent by "acquiring a knowledge base about ethnic and cultural diversity" in their professional education and training (Gay, 2000, p.69). Adding cultural components in teacher education and promoting teachers' cultural competence to better serve culturally diverse students are crucial.

The culturally responsive conceptions of knowledge present new needs for modifying teacher education programs' course settings and curriculum design. Irvine (2003) provided suggestions for accommodating current teacher education programs to train culturally responsive teacher candidates through fostering a knowledge base of culturally responsive teaching. As Irvine (2003) indicated, teacher education students need additional subject matter preparation that emphasizes multiple representations of knowledge as well as pedagogical methods. Every teacher education student needs a major in a content field, along with the knowledge base of cultural diversity and complexity, to become a qualified and effective teacher who have a "deep, thorough understanding of their content as well as repertoire of teaching skills from which they choose and match these skills and content knowledge to classroom behaviors, situations, and students" (Irvine, 2003, p.49).

\section{Practical Implications for Developing Culturally Responsive Teachers}

\subsection{Incorporating Culturally Responsive Knowledge Base into Curriculum and Course Design}

Increases in the number of students from diverse cultural and racial backgrounds in U.S. schools are placing greater demands on teacher education as well as professional development programs for preparing teachers. School educators and faculties in teacher education programs need support and reconstruction in developing teacher education students' and inservice teachers' capacity to provide appropriate and effective instruction for culturally and racially diverse students. Committee on Multicultural Education (2008) addressed this issue in their research by indicating as the diversity of the student population has increased; the instructional practices to address this diversity have, for many teachers and teacher education programs, remained unchanged. As mentioned earlier in this paper, many in-service teachers and teacher education programs use curricula and materials that do not adequately serve the needs of their multicultural students. According to Short (1999), "the lack of familiarity with their students' cultures, learning styles, and communication patterns translates into teachers holding negative expectations for students, while inappropriate curricula, assessments, and instructional materials are used with these students, compounding the problem" (p.107).

The preparation and education for diversity must begin with teachers' themselves. Teachers need to be taught and trained to value, affirm, and maximize the rich cultural heritage their multicultural backgrounds students bring to classrooms (Committee on Multicultural Education, 2008). In this regard, prospective teachers must be educated to differentiate curriculum, instruction, interaction, and assessment to accommodate differences in minority students' learning at schools. Ultimately, as Vavrus (2002) suggested that teacher education programs play a crucial role in determining teachers' attitudes toward diversity and the accommodation of that diversity within their teaching to minority students. Accordingly, teacher education programs need to design the curriculum and materials which could build cross-culturally sensitive and responsive knowledge base to prepare their students.

The course settings and curriculum design which are used to prepare future teachers need to be considered to make teacher education programs become more culturally responsive. Irvine (2008) argued that the demographic changes in today's schools demand new ways of organizing and implementing instruction. As Grossman and his colleagues (2008) argued, teacher educators need to blur curricular lines between what are typically called foundations course and those that focus on methods or teaching. Foundational courses in multicultural education, for instance, "they need to go beyond their focus upon conceptual understandings of racism, injustice, or diversity, they need to help prospective teachers develop a set of specific classroom practices that will help them succeed with students from historically oppressed groups" (p.246). And in turn, methods courses that have typically focused upon teaching subject matter must also address issues of cultural and racial diversity and multicultural education directly, through introducing students to the practices associated with teaching intellectually ambitious subject matter to historically underserved children (Grossman et al, 2008). Irvine (2003) also addressed the importance to develop replicable teacher education models through which teacher education students can acquire multiculturalism knowledge and 
learn to teach culturally responsively.

Vavrus (2002) also proposed to incorporate frameworks to address multicultural education and culturally responsive teaching into the curriculum design of teacher education programs (p.33). Melnick and Zeichner (1997) addressed the importance of the design of the curriculum with culturally responsive perspectives. They indicated that "courses and experiences in professional studies need incorporate multicultural and global perspectives. By doing so, the integrative studies enable candidates to develop meaningful learning experiences for students within the context of students' cultures, language backgrounds, socioeconomic status, communities, and families" (p.24).

According to Banks (1991), school knowledge "should reflect the interests, experiences, and goals of all of the nation's citizens and should empower all people to participate effectively in a democratic society" (p.126). Unfortunately, as Villegas and Lucas (2002) illustrated in their research, the knowledge that is institutionalized in schools and teacher education programs at university levels, does not live up to Banks' standards. Instead, it largely represents the interests of one segment of the population, the dominant group and it fails to prepare students, particularly students from oppressed groups for productive participation in society (Villegas \& Lucas, 2002, p.51).

The bias of the dominant group is most clearly seen in the content of the curriculum setting. Not only are the experiences of past and present members of oppressed groups underrepresented in the curriculum, the knowledge and experiences of individual students from these groups are consistently ignored in schools as well. As Villegas and Lucas (2002) argued, most teachers are not prepared to draw on the background knowledge and experiences of racial and ethnic minority students because they know little about these students' lives and cultural heritages from their training in teacher education programs. Changing the conventional conceptions of knowledge and broadening curriculum and courses with multicultural perspectives could help prospective teachers to embrace "constructivist views" to succeed in becoming aware of their taken-for-granted assumptions about knowledge construction, teaching and learning in culturally diverse classrooms (Villegas \& Lucas, 2002).

\subsection{Diversifying Demographic Representations in Student Population and Teaching Force}

Irvine (2008) proposed that there are too few perservice teacher candidates of color. Zumwalt and Craig (2008) raised the issue that currently, most teachers are female, White and monolingual. According to their study, 84 percent of teachers are White. While the percentage of teachers of color, especially prospective teachers, has increased slightly in recent years, it does not match the increase student diversity. Teachers of color are needed in the profession because their teaching beliefs and instructional practices are related in positive ways to the school achievement of students, especially African American and Latino students, who continue to lag behind White and Asian counterparts academically (Irvine, 2008). Teacher race and ethnicity could influence student learning as well as other important student outcomes such as absenteeism, enrollment in advanced courses, and dropout rates (Villegas \& Davis, 2008).

Much of the arguments for increasing the racial and ethnic diversity of the teaching force to better reflect the diversity of the student population is predicated on the belief that a diverse teaching force is good for all students, regardless of their racial and ethnic background. As Zumwalt and Craig (2008) addressed, teachers of different race and ethnicities can better prepare children for life in a multicultural society committed to equal opportunity (p.411). Relevant researches also suggested that teachers from the same race and ethnic group with their students may act as role models who can instill positive attitudes toward school, create a classroom climate and relationships that lead to greater academic success, and provide culturally responsive pedagogy that will also increase students' chances of academic success (Au \& Jordan; Landson-Billings, Dee, King; as cited in Zumwalt \& Craig, 2008, p.412).

Villegas and Irvine (2010) also advocated for diversifying the teaching force based on three major contributions it could bring to education in the multicultural society and schools: "teachers of color serve as role models for all students; the potential of teachers of color to improve the academic outcomes and school experiences of students of color; and the workforce rationale" (p.176). Their research provide evidence that students of color benefit directly when paired with a teacher of their same race and ethnicity, and indirectly when attending a school system where teachers of racial and ethnic minority groups are equitably represented. The broad body of empirical studies of increasing demographic diversity in teacher education student population and teacher education faculty population indicate that teachers of color have the potential to build bridges to learning for teacher education students and for their future students of color.

\subsection{Situating Teacher Education into Cultural Communities}

Teaching in the culturally responsive ways need both conceptual tools such as the knowledge base and theoretical frameworks of cultural diversity and culturally responsive teaching; it also needs practical tools which encompass the 
kinds of practices, strategies, and relationships that teachers can enact in classrooms as they strive to accommodate the needs of students and challenge them intellectually, rigorous content (Grossman et al, 2008, p.245). In order for new teachers to translate their knowledge base of culturally responsive teaching in the context of their work with multicultural students, they must cultivate classroom practices for identifying students' cultural and community resources as well as adapting subject matter curriculum and instruction to build on and dram from those resources. To achieve this goal, prospective teachers and teacher education students also gain by being educated and trained in a diverse learning community. As Villegas and Lucas (2002) reported in their study, in the absence of racial and ethnic diversity, it is unlikely that teacher education students and preservice teachers will develop the dispositions and skills that characterize culturally responsive educators. Because most White teacher candidates have lived their lives within White communities and have lacked opportunities to learn firsthand about the cultures of people of color (p.154). Such a setting enables them to learn about diversity through direct interactions with people who are racially and ethnically different from themselves, rather than through "decontextualized academic exercises" (Zeichner, as cited in Villegas \& Lucas, 2002, p.154).

The call for increasing field experiences and outreaching to minority communities have long been a part of the teacher education programs. Field experiences that promote culturally responsive teaching sharing a number of salient characteristics: The experiences are carefully planned in advance (Larkin, 1995; Zeichner et al., as cited in Villegas \& Lucas, 2002); and their planning is guided by a theoretical framework and clear pedagogical purposes (Grant, 1997); prospective teachers are also well prepared for the experience before they begin (Villegas \& Lucas, 2002, p.136). Field experiences contribute to the preparation of culturally responsive teachers in a number of ways. Most important, they offer prospective teachers their opportunity to build a contextualized understanding of culturally responsive teaching by getting them out of the university classroom and into schools and communities. Through field experiences, aspiring teachers can also develop strategies for learning about students and communities that they can use when they become teachers (Villegas \& Lucas, 2002). By breaking the wall of limiting teacher preparation in academic classrooms in teacher education programs, reaching out to the communities could actually enrich the effectiveness of preparing teachers for diversity. Learning about communities with which they have had little contact before, teachers-to-be can "begin to see students from those settings as members of family, community, and cultural groups and become more knowledgeable of and sensitive to values, lifestyles, and cultures other than their own" (Zeichner and Melnick, as cited in Villegas \& Lucas, 2002, p.137).

\section{Conclusion}

Darling-Hammond (2008) summarized key concepts within several domains of knowledge base that are critical for teacher education students and prospective teachers to acquire during their professional development in teacher education programs.

Teachers and teacher education students need to obtain knowledge of learners and how they learn and develop within social contexts, including knowledge of language development. They need have understanding of curriculum content and goals, including the subject matter and skills to be taught in light of disciplinary demands, student needs, and the social purposes of education. They also need to gain understanding of and skills for teaching, including content pedagogical knowledge and knowledge for teaching diverse learners, as these are informed by an understanding of assessment and of how to manage a productive classroom (p.1320).

As Darling-Hammond mentioned, in order to help teachers enact effective teaching practices, solid knowledge base and close connection between theory and practice, coursework and clinical work are necessary. Acquiring a culturally responsive teaching knowledge base through foundation and pedagogical courses learning, along with practical field work experiences in communities, could help teacher education students and pre-service teachers to think like a teacher, as well as teach as a teacher in culturally and racially diverse classrooms. Developing a knowledge base with culturally responsive perspectives could assist teachers and teacher education students in developing their cultural understandings and awareness, reducing cultural deficit thinking towards minority students, improving their cultural competences to use knowledge about culture to strengthen the teaching-learning connections and outcomes, crossing multiple cultural barriers, as well as connecting schools and communities.

\section{References}

Banks, J. A. (1991). Teaching multicultural literacy to teachers. Teaching Education, 4(1), 135-144.

Cochran-Smith, M. (2004). Walking the road: Race, diversity and social justice in teacher education. New York, NY: 
Teachers College Press.

Committee on Multicultural Education. (2008). Educators' preparation for cultural and linguistic diversity: A call to action. In M. Cochran-Smith, S. Feiman-Nemser \& D. J. Mclntyre (Eds.), Handbook of research on teacher education ( $3^{\text {rd }}$ ed.) (pp.664-672). New York, NY: Routledge.

Chou, V., \& Sakash, K. (2008). Troubling diversity. In M. Cochran-Smith, S. Feiman-Nemser \& D. J. Mclntyre (Eds.), Handbook of research on teacher education ( $3^{\text {rd }}$ ed.) (pp.686-692). New York, NY: Routledge.

Dillard, C. B. (1997). Placing student language, literacy, and culture at the center of teacher education reform. In J. E. King, R. E. Hollins, \& W. C. Haymany., (Eds.), Preparing teachers for cultural diversity. (pp.85-96).

Dilg, M. (2003). Thriving in the multicultural classroom: Principles and practices for effective teaching. New York, NY: Teachers College Press.

Diez, M. E, \& Murrell, P. (1997). A model program for educating teachers for diversity. In J. E. King, R. E. Hollins, \& W. C. Haymany. (Eds.), Preparing teachers for cultural diversity. (pp.113-128). New York, NY: Teachers College Press.

Darling-Hammond, L. (2006). Powerful teacher education: Lessons from exemplary programs. San Francisco, CA: Jossey-Bass.

Darling-Hammond, L. (2008). Knowledge for teaching: What do we know? In M. Cochran-Smith, S. Feiman-Nemser \& D. J. Mclntyre (Eds.), Handbook of research on teacher education (3 ${ }^{\text {rd }}$ ed.) (pp.1316-1323). New York, NY: Routledge.

Ellerbrock, C. R., \& Cruz, B. C. (2014). A vision of diversity in teacher education. In B. C. Cruz., C. R. Ellerbrock., V. Anete., \& Howes, E. V. (Eds.), Talking diversity with teachers and teacher educators: Exercises and critical conversations across the curriculum. (pp.13-27). New York, NY: Teachers College Press.

Flores, A. (2007). Examining Disparities in Mathematics Education: Achievement Gap or Opportunity Gap? High School Journal, 91(1), 29-42. https://doi.org/10.1353/hsj.2007.0022

Feiman-Nemser, S. (2008). Teacher learning: how do teachers learn to teach? In M. Cochran-Smith, S. Feiman-Nemser \& D. J. Mclntyre (Eds.), Handbook of research on teacher education ( ${ }^{\text {rd }}$ ed.) (pp.697-705). New York, NY: Routledge.

Garcia, E. E. (1988). Attributes of effective schools for language minority students. Education and Urban Society, 20(4), 387-398. https://doi.org/10.1177/0013124588020004006

Gay, G. (1977). Curriculum for multicultural teacher education. In F. H. Klassen \& D. M. Gollnick (Eds.), Pluralism and the American teacher (pp.31-62). Washington, DC.: AACTE, Ethnic heritage center for teacher education.

Gay, G. (1993). Building cultural bridges: A bold proposal for teacher education. Education and urban society, 25(3), 285-289. https://doi.org/10.1177/0013124593025003006

Goodwin, A. L. (2000). Teachers as multicultural agents in schools. In R. Carter (Ed.), Addressing cultural issues in organizations: Beyond the corporate context. (pp.104-114). Thousand Oaks, CA: Sage. https://doi.org/10.4135/9781452231297.n7

Gay, G. (2000). Culturally responsive teaching: Theory, research and practice. New York, NY: Teachers college press.

Garcia, R. L. (2005). Teaching for diversity. ( $2^{\text {nd }}$ ed.). Bloomington, IN: Phi Delta Kappa International.

Grossman, P., McDonald, M., Hammerness, K., \& Ronfeldt, M. (2008). Dismantling dichotomies in teacher education. In M. Cochran-Smith, S. Feiman-Nemser \& D. J. Mclntyre (Eds.), Handbook of research on teacher education ( $3^{\text {rd }}$ ed.) (pp.243-248). New York, NY: Routledge.

Grossman, P., Compton, C., Igra, D., Ronfeldt, M., Shahan, E., Williamson, P. (2009). Teaching practice: A cross-professional perspective. Teachers College Record. 111 (9).

Hollins, E. R. (1997). Directed inquiry in preservice teacher education: a developmental process model. In J. E. King, R. E. Hollins, \& W. C. Haymany. (Eds.), Preparing teachers for cultural diversity. (pp.97-112). New York, NY: Teachers College Press.

Howard, T. C., \& Aleman, G. R. (2008). Teacher capacity for diverse learners: What do teachers need to know. In M. Cochran-Smith, S. Feiman-Nemser \& D. J. Mclntyre (Eds.), Handbook of research on teacher education (3 ${ }^{\text {rd }}$ 
ed.) (pp.157-174). New York, NY: Routledge.

Howard, T. C. (2010). Why race and culture matters in schools: Closing the achievement gap in America's classrooms. New York, NY: Teachers college press.

King, J. E., Hollins, R. E., \& Haymany, W. C. (1997). Preparing teachers for cultural diversity. New York, NY: Teachers College Press.

Knowles, T. (2013). New pathways for teachers, new promises for students. Washington, D.C.: American Enterprise Institute.

Lampert, M. (1985). How do teachers manage to teach? Perspectives on problems in practice. Harvard Educational Review, 55, 178-194. https://doi.org/10.17763/haer.55.2.56142234616x4352

Irvine, J. J. (2003). Educating teachers for diversity: Seeing with a cultural eye. New York, NY: Teachers College Press.

Irvine, J. J. (2008). Diversity and teacher education: people, pedagogy, and politics. In M. Cochran-Smith, S. Feiman-Nemser \& D. J. Mclntyre (Eds.), Handbook of research on teacher education ( $3^{\text {rd }}$ ed.) (pp.675-678). New York, NY: Routledge.

Landson-Billings, G. (1994). The dreamkeepers: Successful teachers of African American children. San Francisco, CA: Jossey-Bass.

Larkin, J. M., \& Sleeter, C. E. (1997) (Eds.). Developing multicultural teacher curricula. Albany, NY: State University of New York Press.

Larkin, J. M. (1997). Curriculum themes and issues in multicultural teacher education programs. In J. M. Larkin, \& C. E. Sleeter. (Eds.), Developing multicultural teacher curricula. (pp.1-16). Albany, NY: State University of New York Press.

Melnick, S. L.\& Zeichner, K. M. (1997). Enhancing the capacity of teacher education institutions to address diversity issues. In J. E. King, R. E. Hollins, \& W. C. Haymany. (Eds.), Preparing teachers for cultural diversity. (pp.23-39). New York, NY: Teachers College Press.

National Center for Education Statistics (2011). Table 291. Received from: http://nces.ed.gov/programs/digest/d12/tables/dt12_291.asp

Pang, V. O., Kiang, P. N., \& Pak, Y. K. (2004). Asian pacific American students: Challenging a biased educational system. In J. A. Banks \& C. A. M. Banks (Eds.), Handbook of research on multicultural education ( $2^{\text {nd }}$ ed.) (pp.542-566). San Francisco, CA: Jossey-Bass.

Rodriguez, F. (1983). Mainstreaming: A multicultural concept into teacher education-Guidelines for teacher trainers. Saratoga, CA: R\&E Publishers.

Shade, B. J. R., (1989). Culture, style, and the educative process. Springfield, IL: Charles C. Thomas.

Short, D. J. (1999). Integrating language and content for effective sheltered instruction programs. In C. J. Faltis (Ed.), So much to say (pp.105-137). New York, NY: Teacher College Press.

Sleeter, C. (2008). Preparing White teachers for diverse students. In M. Cochran-Smith, S. Feiman-Nemser \& D. J. Mclntyre (Eds.), Handbook of research on teacher education ( $3^{\text {rd }}$ ed.) (pp.551-582). New York, NY: Routledge.

Schorr, J. (2012). A revolution begins in teacher education. Stanford social innovation review. Retrieved from http://www.ssireview.org/articles/entry/a_revolution_begins_in_teacher_prep

Villegas, A., \& Lucas, T. (2002). Preparing culturally responsive teachers: A coherent approach. Albany, NY: State University of New York Press.

Vavrus, M. (2002). Transforming the multicultural education of teachers: Theory, research, and practice. New York, NY: Teachers College Press.

Villegas, A. M. (2008). Diversity and teacher education. In M. Cochran-Smith, S. Feiman-Nemser \& D. J. Mclntyre (Eds.), Handbook of research on teacher education ( $3^{\text {rd }}$ ed.) (pp.549-560). New York, NY: Routledge.

Villegas, A. M., \& Davis, D. (2008). Preparing teachers of color to confront racial/ethnic disparities in educational outcomes. In M. Cochran-Smith, S. Feiman-Nemser \& D. J. Mclntyre (Eds.), Handbook of research on teacher education ( $3^{\text {rd }}$ ed.) (pp.583-605). New York, NY: Routledge.

Zeichner, K. M., \& Liston, D. P. (1990). Traditions of reform in U.S. teacher education. Journal of teacher education, 
41(2), 3-20. https://doi.org/10.1177/002248719004100202

Zumwart, K., \& Craig, E. (2005). Teachers' characteristics: research on the demographic profile. In M. Cochran-Smith \& K. M. Zeichner (Eds.). Studying teacher education. (pp.111-156). Mahwah, NJ: Lawrence Erlbaum Associates.

Zumwalt, K., \& Craig, E. (2008). Who is teaching? Does it matter? In M. Cochran-Smith, S. Feiman-Nemser \& D. J. Mclntyre (Eds.), Handbook of research on teacher education ( $3^{\text {rd }}$ ed.) (pp.404-423). New York, NY: Routledge. 